Article

\title{
Pausanian Classification or Socratic Participation: Theologizing the Plurality of Erotic Praxis in Plato's Symposium
}

\author{
Philip Krinks \\ The Centre for Theology \& Community, London E1 0BH, UK; philipk@theology-centre.org
}

Received: 2 August 2018; Accepted: 29 August 2018; Published: 3 September 2018

\begin{abstract}
Read theologically, Plato's Symposium is an exercise in doxology: how Eros is to be praised. Pausanias observes that, since Eros is not one, a unitary praise will be inadequate. Proposing a focus on praxis, he classifies erotic praxes, and praises one, in a synthesis of contemporary convention, sophistic rationality, social responsibility and polytheistic fidelity. Against this Socrates praises erotic praxis as one of a plurality of desires mediating between mortals and an otherwise transcendent good. Desire which is specifically erotic involves a praxis of (pro)creation through attention to beauty. In this praxis mortals participate in immortality and the divine. Pausanias' praise is seriously offered. However, lacking a participatory element, it delivers an underwhelming doxology, making Eros at best an instrument of a sophistically constructed virtue ethic to which his polytheism is ambiguously connected. It is the philosophical theology of Socrates, which, praising Eros as a mediator enabling participation in the divine realm, and offering itself as an analogous form of mediation, is able to be consummated liturgically.
\end{abstract}

Keywords: Plato; Socrates; love; desire; Eros; polytheism; participation; liturgy; doxology; Radical Orthodoxy

\section{Introduction}

Plato's Symposium has been read extensively as a philosophical and as a literary text. Yet its stated purpose is theological. More specifically its purpose is liturgical, indeed doxological: to remedy the lack of 'hymns or thanksgiving songs' (177a6) praising Eros. That lack is contrasted with the poems written for other gods, and with sophists' praises for 'Heracles and others' (177b3), and even for salt. The resulting exchange of speeches has from the start (177e4) a competitive element, with each speaker attempting to improve on what his predecessors offered. Comparisons with sophistic encomia for a hero or mortal are relevant (Nightingale 1993, 1995); but, since none of the first five speakers is willing explicitly to deny the divinity of Eros, some doxological element is unavoidable. Thus, the Symposium, revealed as doxological contest, joins the Phaedrus as an example of Plato's theological philosophy consummated as liturgy (Pickstock 1998).

If the dialogue is a doxological contest, it is also necessarily a credal one (Eidinow et al. 2016). A liturgical view on how Eros is best praised (in theological terms a lex orandi) depends in part on beliefs about who or what Eros is and what is significant about it (a lex credendi). It is not surprising then that each speaker opens with theological comment about the nature of Eros, and develops his praise from there. The theological dimension of Socrates' speech has received some fruitful attention (e.g., Osborne 1994; Kerr 1987; Scott and Welton 2009). The theologies put forward in the earlier speeches have received increasing attention also (Rosen 1987; Strauss 2001; Corrigan and Glazov-Corrigan 2004). This paper contributes to the project of re-reading these early speeches (Nola 1990; Sheffield 2006b) in two ways. Firstly it focuses on the theology offered by Pausanias in his 
speech (180c3-185c4), complementing recent attention to this speech as a political and social document (Ludwig 2002). Secondly it compares Pausanias' speech with a relevant section of Socrates' speech.

Pausanias begins his speech with a complaint about the theological assumptions under which the contest has been set up, and by implication about the doxology of the first speaker Phaedrus. He complains 'that we have been asked to praise Eros in such a unitary (haplōs) way' (180c4). To proceed as if Eros could be individuated as a single thing and discussed in a unitary, or simple, way is a mistake, given the plurality of Eros. This focus on plurality, Pausanias then suggests, should be combined with an attention to erotic praxis. This attention is proposed by way of introducing a principle, which 'holds true of every praxis: being done, itself by itself, it is neither fine nor shameful. But within the praxis, depending on the manner in which it is practised (hōs an prachtei), so it turns out.' (181a1-4).

When Socrates recounts the teaching of Diotima, Eros is first identified as, not a god, but a mediate spirit. The question of plurality returns. Like Pausanias, Diotima is uncomfortable with a notion of Eros which is unitary. Having earlier developed with Socrates an account of Eros as a mediating force, part of humans' orientation to the good, she asks whether it is 'true to say simply (haploun) that human beings feel Eros for the good?' (206a4). She establishes first that this answer is excessively unitary in the sense that further terms need to be added to it. Diotima then addresses erotic plurality as praxis: 'Given that this is what Eros always is, if one considers those pursuing it, in what direction and praxis will their eagerness and intensity be, if it is to be called Eros? (206b1-2). One central section of Socrates' speech (206a4-207a2) is thus dedicated to exploring the plurality of erotic praxis in the way Pausanias had proposed.

After discussing in detail the theology offered in Pausanias' speech (Section 2), a reading is offered (in Section 3) of that central section of Socrates' speech. Examining the theological strengths and weaknesses of each, it is argued (Section 4) that Pausanias' praise is seriously offered: a synthesis of contemporary praxis, sophistic rationality, social responsibility and polytheistic fidelity. Yet comparison with Socrates shows how Pausanias makes Eros at best an instrument of a sophistically constructed virtue ethic to which his polytheism is ambiguously connected. It is the philosophical theology of Socrates, which, praising Eros as a mediator enabling participation in the divine realm, and offering itself as an analogous form of mediation, is able to be consummated liturgically.

\section{Pausanias on the Plurality of Erotic Praxis}

\subsection{Polytheism}

\subsubsection{Divinizing the Unpraiseworthy Eros}

Pausanias is the second speaker, so he has the advantage of being able both to build on Phaedrus' speech, and to contrast his own position with it. Pausanias' view is that Phaedrus has offered a unitary praise. Phaedrus took Eros to be a single divine force, inspiring a single identifiable behavior among human beings, which was praiseworthy within a likewise unitary heroic ethic. Pausanias's reaction to this is: 'If Eros were one,' then the approach of unitary praise would be well enough: 'but in fact he is not one' (180c6).

The suggestion that Eros is plural is far from outlandish. It is an unsurprising response to Phaedrus to say that a faithful homosexual love between heroically-inclined aristocrats (e.g., 178c5-6) is only one behavior which Eros can inspire. One could even criticize Phaedrus as 'preposterous to say ... in general, that Eros is conducive to virtue, since we know of so many cases where Eros has led to vice' (Strauss 2001, p. 61). Furthermore, there was a literary tradition of poetic reference to Eros-es (erōtes) plural. The lyric poets such as Sappho (e.g., Himerius Or. 9.4, page 76 Colonna = Sappho fr. 194) took this plurality for granted. The tragedians built on this, particularly in the contrast with the single figure of Aphrodite. Aeschylus wrote (Suppliant Women 1038) 'to the Eros-es has been given a share of Aphrodite.' Euripides wrote (Medea 843-5) 'Aphrodite sends the Eros-es to sit at wisdom's side, joint workers (xunergous) in every kind of virtue.' 
Furthermore, Pausanias says that one should begin by determining 'which Eros it is necessary to praise, and then to praise it in a manner worthy of a god.' (180d1-3). This strikes two immediately surprising notes, from a theological perspective. Firstly, if all Eros-es are divine, how can some fail to be "praiseworthy"? The poets had plural Eros-es: this could be seen from one point of view as a particularly full-blooded polytheism, a kind of 'ultra-polytheism.' But the poets never drew an evaluative difference between Eros-es, such that one or more of them was not praiseworthy. If one Eros is dubiously divine, this is not an ultra-polytheism, but a polytheism of a kind which is compromised in having to admit doubts about the divinity of some of its gods. Secondly, how is an evaluative judgment to be made, such that one could judge the goodness of a god? Thirdly, while it is no doubt a good liturgical principle to attempt to praise the relevant forms of Eros "in a way worthy of a god," where does that leave the praise of other forms of erotic behavior?

Pausanias will go on to address these questions. For the moment, the pressing question is what a unitary praise is to be contrasted with. Pausanias' objection to unitary praise recalls the famous words of Polyneices, in his exchange with Eteocles in Euripides' Phoenician Women: 'Simple (haplous) is the word of truth; and of complex (poikilon) interpretations justice has no need' (de Romilly 1984; Sansone 1996; Meltzer 2006). For Polyneices haplous connoted a received truth: simple, clear, decisive, plain, open, straightforward, frank. Yet as a critique in the mouth of Pausanias, it must mean 'too simple,' 'simplistic,' 'simple-minded.' Pausanias seems thereby to side with Eteocles, a possibility reinforced by his focus on praxis and the related notion of ergon. Eteocles' objection to Polyneices was that equivalence in words was insufficient and what was needed was deeds: 'But nothing is like nor equal (ison) among mortals, except names; and names are not deeds (ergon) ... ' (1l. 499-502).

Much will depend on what kind of complexity will be in view for Pausanias, and how he will take names to relate to deeds, words to works. If complexity is literally a matter of being 'multiply woven' or 'multi-colored,' as the word poikilonn implies, then that will be no barrier in itself to doxology. The question is how the threads will be woven together. While liturgy does not require a simplistic attitude, it does require a degree of whole-heartedness (Pickstock 1998, p. 42), which in turn require coherence and integration, not only in words, but between words and works.

\subsubsection{Dependencies between Divinities}

As Pausanias begins to identify the Eros which it is necessary to praise, he notes that 'without Eros there is no Aphrodite' (180d3). This could be taken to mean accompaniment: that the two are always together; Eros and Aphrodite are 'inseparable' (as Jowett 1871 translates). That would mean that the activities associated with Aphrodite are always to be found where the activities related to Eros are found. As such it recalls Hesiod (already mentioned by Phaedrus in his speech): Eros was with Aphrodite from the beginning of her life. ' . . E Eros walked beside her, and Longing (Himeros) followed her, both at her birth at the first, and as she went into the assembly of the gods ... ' (Theogony 202-3). Since Aphrodite meant sex, and the cognate verb aphrodisiazo to have sexual intercourse (Allen 1993, p. 16), and Eros meant desire, he could mean, as a generalization, there is no sex without desire.

Alternatively, his words could suggest a dependency of Aphrodite on Eros. Yet Pausanias' next remark, as well as confirming the number of Eros-es as two, has the implication that in fact Eros is dependent on Aphrodite, in at least one regard. This is that the count of Eros-es is said to be dependent on the number of Aphrodites: 'if there were only one Aphrodite there would be only one Eros; but as there are two goddesses there must be two Eros-es also' (180d4-5). That dependency is the one more consistent with the lyric poets such as Simonides (e.g., 575 in Page 1962; cf. Breitenberger 2007, p. 168). For them Aphrodite was the mother of Eros: in which case, it would be more relevant to say that, in one very real sense, without Aphrodite, there is no Eros.

\subsubsection{Dividing Aphrodite}

The claim that there are two Aphrodites stretches even an ultra-polytheistic frame. But more specifically it was a comprehensible claim in two senses. Cultically, as would have been well-known to the 
symposiasts, there were two separate sanctuaries of Aphrodite on the acropolis (Breitenberger 2007, p. 32), in which Aphrodite was worshipped under two different aspects. The first was Aphrodite Ourania, meaning literally 'Daughter of Heaven (Ouranos) ... worshipped under the aspect of reproduction': this was the more recent sanctuary, established in the agora c.500 BC (Breitenberger 2007, p. 32). The second was Aphrodite Pandēmos, in a somewhat older sanctuary, a cult name meaning literally, 'Of the whole people' and 'associated with a rather abstract, political principle, civic harmony' (Breitenberger 2007, p. 32). This represented 'the highest political idea to which Aphrodite attained' (Oxford Classical Dictionary, 2nd ed., s.v. Aphrodite, quoted in Corrigan and Glazov-Corrigan 2004, pp. 61-62). Abstract and aspirational as these theologies may be, by referring to them at all, Pausanias' approach is realistic, given the contemporary context in which religious and political institutions were closely related (Most 2005, p. 34).

In literature, there existed two antique genealogies of Aphrodite, to which Pausanias also refers: 'the elder one, motherless, whom we call Heavenly (Ouranios); the younger one, the daughter of Zeus and Dione, we call of the people (Pandemos)' (180d6-e1). This first genealogy, of Aphrodite Ouranios, is from Hesiod's Theogony (188-192, 195 ff.) where the birth of Aphrodite is literally, mother-less, born from a sea-foam emerging from the castrated testicles of Heaven (Ouranos): 'a white foam spread around them from the immortal flesh, and in it there grew a maiden ... Her gods and men call Aphrodite ... ' The second genealogy is found in Homer, where Dione is said to be Aphrodite's mother (Iliad 5.370-430). One can see why Pausanias conceives of these as different goddesses. Hesiod says his Aphrodite is motherless; Homer says she is the daughter of Dione.

Pausanias is building up his account in stages. The notion of two Aphrodites is suggested by contemporary cultic practice and the literary tradition. Two Aphrodites, together with the association of Eros and Aphrodite, give him the conclusion he needs about two Eros-es. Furthermore, he is able to assert the association of Eros and Aphrodite without ever stating a hierarchy between them. That is to be avoided, theologically. For Eros to be subsidiary seems to make his praise unsatisfactorily dependent on hers; and for Aphrodite to be subsidiary seems unthinkable. For Aphrodite certainly stands on her own two feet, as it were. Even if Aphrodite had made a relatively late entry into the Olympian pantheon, it was Aphrodite, not Eros, who was the canonical love goddess with the major cults at Athens at this time (Breitenberger 2007, pp. 10-44).

Usually one would not think that Aphrodite being worshipped under two aspects was the same as there being two Aphrodites. In Xenophon's Symposium (8.9) Socrates specifically questions this implication (Hunter 2004, p. 45). The two cults would have been thought to be worshipping the same goddess Aphrodite but under two different aspects. But then there are the literary genealogies. These first of all have the benefit for Pausanias that he meets the previous speaker, Phaedrus, on Phaedrus' own ground. Thus, he can build on Phaedrus' principle that the genealogy of something discloses something about it, as two separate Aphrodites are supported by the inconsistent Homeric and Hesiodic genealogies. Then Pausanias can nuance between the idea that Eros itself might have two different aspects, and the implication of two goddesses, implying rather two separate Eros-es. At the same time Pausanias does not introduce the two additional names of desire, Pothos (Yearning) and Himeros (Longing), found in lyric poetry for different Eros-es: thus, he leaves it open that, while there may be two divinities, they can still both rightly be called Eros.

\subsection{Plurality of Divinities Connected to a Plurality of Erotic Praxes}

\subsubsection{The Nature of the Connection between the Divinity and the Praxis It Inspires}

Pausanias' next objective is to connect antique theogony with contemporary praxis. He explains that one way in which 'there is no Aphrodite without Eros' is that Eros is a co-worker (sunergos), with Aphrodite. 'Necessarily the Eros which is a co-worker (sunergon) with the second Aphrodite is correctly called Of the Whole People (Pandēmos); and the other Heavenly (Ouranios).' (180e2-3). To be exact, the two Eros-es pair up and act as co-worker with one Aphrodite each. 
The notion of co-working recalls the passage from Medea quoted above. It also illustrates the central challenge Pausanias has to face: that it is crucially not the case that both Eros-es can be thought co-workers with Aphrodite in inspiring virtue. Even on his own account, it seems that only one pair of Eros and its co-working Aphrodite are co-workers in virtue, and the other pair are doing something else.

At the same time, it is a general theological principle, that, as Pausanias says, almost by way of a throwaway remark, 'one should praise all gods [and goddesses]' (180e3). This comment marks a shift (Hunter 2004, p. 44) from a Hesiodic tone, to something which seems initially very surprising: the strong focus on erotic praxis Pausanias now proposes at 181a1. For if one focuses on praxis, that will include the less acceptable praxis. If one further takes the polytheistic view that a praxis is inspired by a related divinity, then in the case of one form of Eros, the general principle of the praiseworthiness of the divine would be violated.

Yet Pausanias says something quite specific: that a praxis, 'being done, itself by itself, is neither fine nor shameful.' This is his 'fundamental thesis' (Corrigan and Glazov-Corrigan 2004, p. 57). For evaluation, one must look within the praxis. For 'depending on the manner in which it is practised, so it turns out: if done rightly it becomes (gignetai) fine, and, if not, shameful.' (181a2-5). This seems at first sight to be simply circular (Anderson 1993, p. 27), if it means only that noble and shameful are defined in terms of nobility and shamefulness. It has also been objected that it is an objectionable principle, since 'murder cannot be done nobly' (Strauss 2001, p. 65; Corrigan and Glazov-Corrigan 2004, p. 61 offer a similar objection). However, it is not entirely circular, for it suggests that one must locate evaluation at the right level. Ethical evaluations may be better made at a more specific level than the level of the praxis itself, which is then 'morally neutral' (Sedley 2006, p. 63). Similarly, Pausanias might respond to Strauss by saying that he considers killing a praxis, and killing in a just war to be noble. Pausanias wishes to use this difference of level to preserve a good deal of ambiguity about the nature of the connection between divinity and praxis.

Furthermore, he says that 'one must try to say what things each has ended up with (eilêche)' (180e3-4). The word eilēche means literally 'gained by lot.' It appears Pausanias' conception of the nature of the two pairs is one where it is somewhat accidental which behaviors end up 'associated with' each pair. That is a further way of protecting, so to speak, one Eros/Aphrodite pair from association with a less praiseworthy praxis.

Pausanias has so far created a twofold scheme: at one level a god and goddess; at another level, a certain praxis ambiguously related to them. This second is potentially plural in its own right. For internal to the praxis (literally 'within it' or 'in it') there are different styles or manners of the practicing which contribute to the ethical evaluation of it. This latter begins to relieve the tension generated by a combination of polytheism and a realistic ethical assessment of some erotic praxis. This tension Pausanias frankly admits: 'Not all Eros is fine and worthy to be praised; but only the Eros which sets us to desire (literally eran, 'to feel Eros') in a fine way' (181a4-6).

\subsubsection{The Gods and Their Followers}

This unpraiseworthy love is then discussed from 181a8 to 182a7. Pausanias' desire to protect the relevant Aphrodite/Eros pair from the negative evaluation associated with the praxis they are said to inspire is shown in the way he presents this. When he discusses this unpraiseworthy love, his focus is on the characters of the people involved: inferior (phauloi) people. He nuances the question of whether this is due to the gods involved. He says (181c5) this inferior behavior is due to two characteristics of Aphrodite of the Whole People. Firstly, she is younger, which presumably explains why it is less restrained (the old 'have no share of transgression' 181c5). Secondly, she had parents of both sexes, which presumably explains why it is bisexual. These points in themselves do not compromise the praiseworthiness of the goddess.

The problem lies with the individual lovers and their character: a third aspect which he has thereby introduced into the scheme. This aspect is evaluatively significant here, for Pausanias implies 
that it is this inferior character of those following the relevant Aphrodite/Eros pair which leads them to be inspired to an unpraiseworthy praxis; while those aspects of Aphrodite which inspire them, such as youth and male/female parentage, are in themselves neutral. Thus, he holds a delicate balance between saying Aphrodite and/or Eros are to blame; and undermining their divinity in a different way by giving an explanation which would make Aphrodite and Eros irrelevant.

Pausanias then cleverly strikes this balance in the reverse manner in the following passage on the Heavenly Eros. Here the main emphasis is on the genealogy of Heavenly Aphrodite and its implications. Since, in her parentage, she does not share in the female, only in the male, the Heavenly Eros is exclusively homosexual. Since she is older, this Eros has no share of transgression (hybris, 181c5). When one sees people showing praiseworthy behavior, such as focusing erotically, not on young boys, but those who are slightly older and beginning to be fully developed intellectually, one can see, he says, that their impulse is from Heavenly Eros. What is emphasized this time, in the case of the praiseworthy praxis, is that it is the god and goddess who are to be praised for this. It is not until $181 \mathrm{e} 3$ that the character of these lovers is discussed specifically, and even then, only parenthetically.

This threefold scheme has allowed Pausanias to have it both ways. He argues, on the one hand, that, when erotic activities are shameful, it is the inferior character of the people which is to blame. But when erotic activities are praiseworthy, as in the homosexual relationships he defends at 181c3-182a2, that is due to the characteristics (genealogically understood) of the Aphrodite in question, and only parenthetically due to the good character of those people. And in neither case, does he emphasize that Eros is the cause-which further insulates Eros from blame for the unpraiseworthy praxis.

\subsection{Ethical Relativism}

\section{The Role of Conventions}

Pausanias does not specify at the outset what kind of normativity is in play. His hearers have been left to wonder on what basis a praxis (or in fact the manner in which a praxis is done) can be evaluated; and indeed, what the basis would be for saying a person is inferior. It now turns out that the notion of nomos (convention) plays the central role in Pausanias' thinking about evaluation. This will constitute a fourth element in the scheme he presents.

One might expect nomos to be used descriptively: to refer to the social conventions which can be observed to be prevailing at the time. But from the outset that is not the case. The notion of nomos enters Pausanias' speech, when he comments on the unpraiseworthy erotic praxis. He expresses his point about the inappropriateness of loving young boys as: 'there ought to be a convention (nomos)' (181d7) against it. Then, the point about the character of the lovers who practice the behavior associated with Eros paired with Aphrodite Ourania, restricting their Eros to mature young men (181e3), is that such 'good men lay down this convention for themselves.' What is notable about these remarks is that neither in fact reports a prevailing social convention at all. At $181 \mathrm{~d} 7$ there 'ought to be' a convention - but there is not. At 181e3 the convention is one that men, if they are good men, lay down for themselves, which, one might think, is not exactly how social conventions work.

The latter point becomes more pressing at 182a, when it becomes clear that Pausanias' view of the kind of Eros which is fine is actually not conventionally widely accepted, but controversial: some people in fact say that it is shameful to grant favors to older lovers (182a4). This is the first explicit reference in the dialogue to Eros being evaluated negatively, and it is an attack aimed specifically at the homosexual Eros which Pausanias says is not only defensible but praiseworthy. It may be praiseworthy in his view, but it is not simply conventionally praiseworthy.

It is certainly true that Pausanias favors conventions of certain kinds: 'not all laws are equally good' (Dorter 1969, p. 218; Corrigan and Glazov-Corrigan 2004, p. 61). In particular, conventions must not be unitary, nor thought to be unitary when they are in fact not. He disapproves of 'the convention (nomos) about Eros, in other cities.' It is easy to grasp. But 'it has been defined simplistically 
(haplōs)' (182a8-9). To say that relevant conventions about Eros are plural and need to be grasped city by city is not surprising (Bury [1932] 1973, p. xxxvii). It is surprising, however, to say that simplicity of convention is itself problematic. Fortunately, however, in Pausanias' view, 'here [in Athens] and at Sparta, [the convention] is complex (poikilos)' (182a9-b1). Pausanias continues with the assumption that, if one can be subtle, one will be. The cities who have simplistic conventions have them because they lack the capability and sophistication for complexity: in Elis and Boeotia, for example, people are not clever speakers (sophoi legein, 182b2). The cities which proceed in a simplistic way are the less sophisticated Greek states and barbarian tyrannies, to be contrasted with the sophisticated superpowers of Athens and Sparta. It is too imprecise to say that this is an Athens-centric view of the matter. Rather this is the view of those in contemporary Athens who saw sophistic developments in rhetoric, politics and ethics as an improvement, against Polyneices and the traditionalists.

In fact, it turns out that even one convention, however subtle, is too simple. For, after Pausanias has dealt with incorrect views about supposed Athenian conventions (a first incorrect view at 182d5-183c4, then a second at 183c4-d3) he states instead a third and correct view (183d4-185b4). What is distinctive about this third view is firstly that it is formed by those able to look beyond either the first or the second supposed conventions, rather than those whose thinking on the matter $(182 \mathrm{~d} 4,183 \mathrm{c} 2,183 \mathrm{~d} 3)$ is solely influenced by one of them. Secondly it does not assume the Athenian view is simple (haploun, 183d4). Thirdly it consists in accepting that what is praiseworthy is the conjunction of two further conventions, of in fact a plurality of conventions: 'Two conventions (nomō) must be combined to create the conditions in which it is a fine thing for a boyfriend to do a favor for his lover: the rule about Eros for boys, and the rule about the love of wisdom and the rest of virtue.' (184c7-d2). If this plurality of conventions comes to a unity, it is in a transaction or exchange, of a putatively reciprocal, but asymmetric nature. The conventions to be satisfied are for the older lover to have a reputation for virtue; while the young one must desire to be educated and inducted into political participation. In favor of this asymmetry is the point that, to take it on its own terms, if the relationship had been symmetrical, its educative value would have been reduced.

The question which arises about this third view, is whether it is a broadly prevailing convention at all. One possibility is that Pausanias has made a correct observation about the combination of these two customs being in fact the prevailing social norm, which others have missed: he has looked better at what is happening, or he has been able to theorize it better, or both. It is certainly true that elements of what Pausanias defends were known aspects of Athenian homosexual praxis: the elder lover was assumed to have wisdom, a grasp of the virtues (184c7-d3) to pass on (Ludwig 2002, p. 29). Such homosexual relationships were taken to play a useful educational and social role as a method for the transmission of virtue (Brisson 2006, p. 235). In that sense to praise these relationships could be seen as a matter of social responsibility, as they enabled education and civic participation of young men.

Yet, from what Pausanias himself has said, it would seem this was at best a controversial view. 'Pausanias is moved ... to a sophistic revision or interpretation of convention' (Rosen 1987, p. 61). The text certainly leaves open that Pausanias may be proposing the former: 'a subtle change' (Strauss 2001, p. 82). This is shown to be possible by the way he describes the status of this third view: that it 'has been taken as a convention for us' or 'by us' (nenomistai hēmin). Rowe (1998) well translates this phrase to preserve the ambiguity: 'It is our considered view that ... .' What is ambiguous is whether the 'our' in question is Athenian society as a whole, or a subgroup of sophisticated thinkers, or even Pausanias speaking for only himself and his partner Agathon. He did not previously appear bound by prevailing norms. Taking Pausanias' speech as a whole, its length and tone may partly reflect the fact that convention, and indeed, in the broadest sense, the force of 'law [was] not entirely on his side and yet he needs the law' (Strauss 2001, p. 87).

At any rate Pausanias does not tell the whole story. Certainly, the younger man was educated by the older, and in some cases the older lover received sexual favors in return for providing education (Dover 1978, p. 204; Halperin 1986, pp. 63-66; Ludwig 2002). This is why some opposed, or even 
ridiculed, such praxis. There are reasons to think that the third view is Pausanias' own proposal: a proposal for a new convention, not widely held.

Either way, the fifth element in Pausanias' system, implicit but crucial, is sophistic intelligence, which is required in either case. If morality is a matter of recognizing and articulating the prevailing social conventions which are complex, sophistic intelligence is needed to recognize and articulate them. If what is needed is to propose new but acceptable complex conventions, it is needed to propose them. On Pausanias' account plurality and complexity have turned out to be pervasive: from the divinities to the praxes to the individuals and the ethical conventions about them. No account based on one divinity or praxis or group or convention is sufficient, so a unitary praise is indeed inadequate. Subtle classification is required everywhere, and valuable indeed is the thinker who is capable of it.

\section{Socrates on the Plurality of Erotic Praxis}

\subsection{Specifying Eros: Eros as Personal and Permanent}

\subsubsection{Unitary Account}

Just as Pausanias begins from the speech of Phaedrus and his unitary understanding of Eros, so in Socrates' speech by 206a1 he and Diotima have reached agreement that 'there is nothing else that people feel Eros for except the good.' This is an understanding of Eros as the desire which human beings feel for the good, mediating between us and the good. What characterizes desire is taken to be its object. Goodness attracts, drawing us as it were magnetically, and Eros is the state of responding to that (Murdoch 1993, p. 343f). Yet, like Pausanias, Diotima is concerned that this account is too unitary. She asks: 'Is it true to say simply (haploun) that human beings feel Eros for the good?' (206a5). Socrates portrays himself as finding it adequate (206a6) but Diotima corrects him.

\subsubsection{Personal and Permanent}

The unitary account is inadequate in two ways. First of all, Diotima asks, 'But shouldn't one add that they feel Eros for the good to be for them ...' (206a8). One does not only desire only that the good should exist, but that it exists in relation to oneself. Rather than possessiveness, this expresses a less specific personal orientation: a desire to have a personal relationship with what is good, as earlier when Diotima had Socrates say that one desired beautiful and good things so that they 'would come to be for him' (204e4, Nye 1994; Costa 2006). The phrase could be taken as having a possessive import (so Nygren 1953, p. 180, n. 1 with Vlastos 1973, p. 20, n. 56), but the later examples at 205d4 already stretched a conventional sense of possessiveness. While that might have been encouraged by the example of making money, it is stretched by the other examples, of physical health, and the wisdom arising from philosophy.

Diotima goes on to add: 'Not only for it to be [for them], but for it always to be [for them] ... So that, in summary Eros is for the good to be for oneself forever.' (206a9-12). Eros then also involves an orientation to permanence: the good is conceived of as always good, so one's desire for it is neither temporary or time-bound. This opens up the sense of the good as something to which one might have an orientation which goes beyond a mortal lifespan.

Even in these few lines it becomes clear that Diotima is opening the way for an understanding which is not unitary, any more than Pausanias' was; but which is non-unitary in three starkly different ways. Firstly, this non-possessive personal relationship suggests a participation of the individual in the good with Eros as mediator. Thus Eros cannot be understood in isolation from the individual and the good, or from its mediating role between them: Eros is not one thing, in the sense that it is irreducibly not something which can be separately understood. This also implies that the individual herself is not to be understood except in the light of the good and the Eros which mediates between them (McCabe 1994). 
Secondly, if human beings have desires which transcend their mortal life, and so their mortality, this suggests the possibility of the good transcending the goods of mortal life, stretching into an infinity of time: 'an eternal, timeless Good', which could then be thought part of 'the realm of the divine' (Scott and Welton 2009, p. 183).

Thirdly, the possibility of eternal personal association with the good suggests the possibility of the good stretching into an infinity of not only time but value. This might seem unsettling. It could be said that, if Eros is for a good of that kind, then Eros is so far from being unitary that it is indeterminate. It would be fairer to say that such an account leaves Eros itself under-determined, with all dependence resting on the good as a transcendent source (McCabe 1994, pp. 62 ff.; Pickstock 1998, p. xii). The good to which Eros mediates then stands as an 'inaccessible and inexhaustive plenitude ... . a beneficent mystery,' as Pickstock puts it (Pickstock 1998, p. 11).

\subsection{Discussing the Plurality of the Practices of Desire}

\subsubsection{Plurality and Praxis}

Diotima does not wish to deal only with the question of plurality. She, like Pausanias, wishes to address it with a specific focus on praxis. The words Socrates reports pick out with apparently deliberate emphasis what Pausanias said earlier. Diotima says: 'Given that this is what Eros always is, if one considers those pursuing it, in what direction and in what field of activity (praxei) will their eagerness and intensity be, if it is to be called Eros? What is the function (ergon) of Eros?' (206b1-3) Praxis explicitly recalls Pausanias (at 181a1, a3). Tropos (direction, literally 'turning') recalls that 'not all love is worthy to receive an encomium but only that which turns us forward to desire in a fine way (181a7). Ergon recalls the role of Eros as sunergon (180e2) and on what it works through to (exergazertai, 181b1), and also further recalls Eteocles' emphasis on deeds.

Yet for Diotima praxis is too cold a term in isolation. The heatedness which in Pausanias was a form of immoderate hot-headedness is not unpraiseworthy. She acknowledges that Eros is 'tension, exertion, zeal', as Iris Murdoch puts it: a primary point of Diotima's account is to acknowledge the spiritual energy associated with Eros and to relate this to its goal, allowing the exaltation of 'perfect good above imperfect love' (Murdoch 1993, p. 343).

Diotima, in connecting the plurality of erotic praxis with the range of specific goods which might be desired, builds on the earlier agreement that 'we distinguish one kind of love and give it the name Eros which in fact belongs to the whole' (205b4-6). The question now is what marks out that Eros-usually-so-called, a moment of analogical specification. (If seen as an analogy, some of the scholarly concern-Price [1989] 1997, p. 25; Rowe 1998, ad loc p. 181; Sheffield 2006a, p. 85, n.13-about how Diotima can be read as narrowing the focus of discussion is allayed.)

When Socrates professes ignorance about what distinguishes Eros-usually-so-called, Diotima offers the famous answer: 'It is procreating (tokos) in beauty, both through the body and the soul.' (206b5). What characterizes Eros, as opposed to other practices of desire, is, firstly that the praxis, direction and function of it is procreation. Diotima uses the verb tiktein ('to procreate') with cognate noun tokos (procreation) to mean (re)produce, (pro)create, be creative.

Secondly, there is a connection to beauty, not now as the object of Eros, but as catalytic in the process of procreation. Beauty is central and required: 'salvation is by beauty' (Weil 1957, p. 143; compare Murdoch 1993, p. 16). 'Eros is a form of the desire for immortality, for perpetual possession of good ... a yearning to create in and through beauty' (Murdoch 1993, p. 415). Beauty is not to be consumed or damaged in the process, as it might be if it were instrumental. Indeed, for all that is said here, the beautiful in question may even find some of its fulfilment in participation in this process.

\subsubsection{Being Together}

Mediation of a different kind is required even to understand what Diotima says: Socrates, apparently uncomprehending, says that one must have the gift of prophecy to understand. That draws 
from Diotima the explanation that 'All human beings are pregnant (kuousin) in body and in soul, and, when they get to the right age, our nature desires to procreate (tiktein). It is impossible to procreate in the ugly, but [it is possible] in the beautiful.' (206c1-4). Being pregnant in body and giving birth and so physically procreating is a comprehensible enough idea, and it is clear enough that that is part of the ergon of specific Eros-usually-so-called (Scott and Welton 2009, p. 121). What being pregnant in soul means will be explained later at 209a3.

The words for pregnancy and procreation suggest a woman's time of pregnancy and childbirth, so that the focus is heterosexual. That is explicit in the line, 'The sexual intercourse (sunousia) of a man and woman is a giving-birth (tokos),' if it is retained (Pender 1992, p. 74). One ground for deleting this from the text as a gloss, as many editors have, is that it might be taken as obvious (Vlastos 1973, p. 21, n. 60). While the focus is heterosexual, and one could give an account of intercourse and birthing focused reductively on the survival of one's own family, or the species as a whole, this is far from being the line Diotima takes. 'This is a divine thing, and an immortal thing in a mortal (thnētōi) creature (zōioi i): pregnancy and reproduction (gennēsis).' (206c4-7). How can a mortal participate in immortality? 'Humans can never become immortal, because if they did they would cross the boundary which forever separates humans from gods. Through generation, however, humans can attain a kind of immortality, the only kind available to them' (Most 2005, p. 37).

The divine status which was denied to Eros (202b7) is already at 206d1-2 granted to beauty. What is beautiful is first said to fit (harmotton) the divine. Then Diotima personifies beauty as Kallone (Price [1989] 1997, p. 15), apparently an innovative theological acclamation (Smothers 1947, p. 27; cf. Usener 1868, p. $368 \mathrm{ff}$.). It is this divine Beauty who presides at birth (206d1-2). Thus, Kallone supplants the traditional role of both Moira (Destiny) and Eileithuia, the goddess of childbirth who had traditionally attended the deliveries of gods and heroes (Baur 1902; Willetts 1958).

The language of the following lines is not only bodily descriptive, but 'sexually explicit' (Anderson 1993, p. 73). The verbs used express 'the reactions of the male and of the female genitals to sexual stimulus or revulsion' (Dover 1978, ad loc., see also Rowe 1998, ad loc.). At the same time Diotima is not giving a biology lesson: the context is 'impressionistic ... rather than ... precise' (Rowe 1998), 'blurring the distinction' (Price [1989] 1997, p. 15) between the male and female roles. What matters is that there is a physical release, a release from 'great pain' (206e2), which depends on the presence of the beautiful as exterior. Only in such a presence can the self be willingly opened to what is exterior (Pickstock 1998, p. 31). 'By a mysterious alliance ... the desire for propagation is aroused only by beauty, carnal beauty ...' '(Weil 1957, p. 144). Against any attempt to stylize Socrates' speech as dualist and focused on interiority, Diotima could not be more explicit in stressing a participation of the whole person (Pickstock 2001b), and a bodily response to what is exterior, since it is by procreating in the body that participation in the immortal occurs (Pickstock 1998, pp. 19, 30).

Yet still it is not the beautiful which Eros seeks (206e2-3), but rather to have a share in divine immortality. This is an important difference, more 'deliberate' (Cleary 2007, p. 133) than 'subtle' (Sedley 2006, p. 49). 'It is of generation and procreation in beauty ... . Why is Eros of generation? Because (pro)creation is everlasting and immortal, insofar as those are possible for mortal being ... ' (206e5-207a1). The conclusion reached at the end of this exchange is that beauty mediates between us and the immortality we seek in our desire to transcend mortality: 'it is necessary, based on this discussion, that Eros is also for immortality.' (207a2). So far, the focus has been on physical procreation: 'we have the power to create, and only the beauty we love can release that power' (Vlastos 1973, p. 21). A comprehensive account of the reason that this transcendence of mortality is significant, and the range of ways in which it can occur, will take up the rest of Socrates' speech.

The positive evaluation which has been offered of heterosexual intercourse is starkly different from Pausanias' rejection of the Eros paired with Earthly Aphrodite as unpraiseworthy Eros. That Aphrodite stood condemned, as Allen puts it (Allen 1993, p. 15) as Venus Meretrix. Yet she is also Venus Genetrix, in contrast to inherently biologically infertile Heavenly Aphrodite. For Diotima, on the other hand, this heterosexual Eros is, not so much epithetically Heavenly (Ouranios), as specifically divine (theion), 
or 'godly' (Scott and Welton 2009, p. 122). Furthermore, since heterosexual Eros leads to the birth of children and so to the succession of generations, the immortality it thereby provides confirms the place of Eros as a desire for the good to be for oneself forever (Allen 1993). Plurality is not narrated here in terms of orientations subjected to an evaluatory classification: for those who are not so pregnant in their bodies and drawn to heterosexual procreation, Socrates will later present the no less honored possibilities of pregnancy in soul.

Whereas Pausanias' classifications seemed to lead to fracture and fragility, Socrates offers us the concept of a single good, the instantiations of which can be expected to be able to be integrated. The dialectic difference in play in this Platonic theology is something other than sophistic classification (Pickstock 1998, p. 17). Central to this integration is the notion of immortality, which connects procreation with permanent possession of the good. Some might find paradox here, as Socrates implies: 'procreation is everlasting and immortal—insofar as those are possible for mortal being.' Yet in this participatory scheme it is not surprising that mortals should seek to achieve some measure of immortality. The procreation of children from the heterosexual Eros which Socrates has defended yields a form of often welcome, if always vicarious, immortality. This confirms this form of Eros as mediating, like all desire, between mortals and the good, a praxis of (pro)creation, in which mortals participate in immortality and the divine.

\section{Discussion}

\subsection{Doxology and Plurality}

When these two accounts of erotic plurality are compared, there are points of both similarity and difference. At the level of praxis both speakers have in mind an erotic praxis which is the focus of their praise. For Socrates this is, in the section in focus here, the physically procreative orientation of heterosexual Eros. For Pausanias, it is homosexual relationships with appropriately aged youths oriented primarily to self-improvement. Both speakers leave some Eros outside the scope of their praise and leave it unpraised since unpraiseworthy.

Socrates and Diotima, in not accepting the unitary definition of Eros as desire for the good, and considering first its personal and permanent nature, and then the nature of Eros-properly-so-called with all its familiar energy and urgency, offer a specification within their unitary definition. This is explicitly one of a plurality of possible specifications. Furthermore, while for Socrates Eros is, at its best, oriented towards the good, there is room for the truth that Eros is not always at its best. It may be focused on an object which is believed to be good, but not so, so that there is a failure to achieve the hoped-for participation in the good. In one sense this is still Eros: it remains a desire for the good. Yet in another sense it is not Eros, since it is not the good de re to which it is oriented. It is a case of 'mistaken identity, like someone who runs joyfully down the street toward a stranger whom at a distance he mistook for a friend' (Weil 1957, p. 130). Socrates, while restricting the scope of praise, is able to praise all Eros which is really Eros, since he has an account of how the "unpraiseworthy Eros" is a distorted pursuit of an intelligible good (Ritchie 2012, p. 103). A proper doxology allows that 'Eros is the desire for good which is somehow the same even when a degenerate good is sought' (Murdoch [1977] 1998, p. 418).

For Pausanias also, the Eros classified as unpraiseworthy is still Eros: all erotic praxes which go by that name are forms of Eros. Thus, he relates the different erotic praxes in his classification to each other, and so to the focus of his doxology. It is not possible, however, for Pausanias to maintain whole-heartedly that all erotic praxis is inspired by a god. This in itself hampers his doxological project. It also reveals an additional problem. If the divine influence is ambiguous, then, for all Pausanias says, the relationship of the different Eros-es to each other is a relation in name only. The gods and activities he is classifying are included in the classification on the basis of name alone. Such a form of linguistic conventionalism can come in a more or less problematic form. There is a respectable place for a focus on ordinary language; as there is for beginning to theologize and philosophize from within 
inherited tradition. But where the conventions are created by the individual, one has linguistically a private language, or ethically a private morality. There is a risk of asserting, in Eteocles' terms, an 'equality in names,' which is not (even) recognized by others. Pausanias' approach to theologizing pluralism —and with it his whole project of doxology—are thereby at risk of dissolving, as Polyneices feared, into sophistic nihilism.

\subsection{Divine Participation}

Socrates emphasizes the notion of participation. For Socrates, erotic praxis is in itself a divine thing, an immortal thing in a mortal creature. Socrates thus advertises his account of divine participation openly: participation in the divine life through a good which is such as to attract human desire through its beauty. Eros itself, and its specific practices, mediate in the doxology between the lover and the good. This does not thereby instrumentalize Eros, or the sensible good and beautiful things which attract the lover. The mediation in question is one which one wishes to be eternal, and which is necessary as the way of eternally participating in the good and beautiful. What mediates, if permanently and necessarily, is valued not only contingently, temporarily and hypothetically. A mediating erotic praxis may be constitutive of human flourishing conceived eudaimonistically (Sheffield 2006a, p. 28). That which mediates to what is ultimately valuable cannot, in a participatory scheme, be taken as therefore only instrumentally valuable (Milbank and Pickstock 2002, pp. 47-51). This is where Vlastos goes wrong in his famous line criticizing Plato, that Plato bids us 'love the persons ... only in so far as they are good and beautiful' (Vlastos 1973, p. 31). In assimilating Plato's thought to Kant's, and imposing a Kantian dichotomy between self-interest and a disinterested altruism, he misses the ethical implications of a metaphysics of participation and mediation. Against Vlastos' remark about loving persons as they are, is to be placed the 'inexhaustive plenitude' of a transcendent good (Pickstock 1998, p. 11) from which may flow complex, multi-colored, multi-woven value. So far from 'love of that abstract version of persons which consists of the complex of their best qualities' (as Vlastos 1973, p. 31 interprets Diotima's recommendation), Diotima's proposal instead opens room for a quite different idea. This is that someone might be filled with 'a love of the beauty of the world' (k): like Pablo Casals in Gaita's example, filled 'with awareness of the wonder of life ..., with ... amazement at the miracle of nature' (Gaita 1999, p. 219; 2004, p. 213).

Pausanias, however, does not have an account of participation. Indeed, one purpose of his fivefold schema is to create various limitations and ambiguities about the degree, even, of divine influence on the world. The differently praiseworthy erotic praxes are not said to be due to the influence of the two Eros-es: the gods are associated with the praxes only ambiguously and contingently. This move is necessary, I have argued, to protect his divinities from a negative evaluation, as inspiring the wrong kind of behavior. Yet if gods are not able to influence human affairs nor humans to participate in the life of the gods even to the extent of being so influenced, there is no substantial participation. For Pausanias, erotic praxis does not mediate such a participation, but serves as a buffer layer between: on the one hand, evaluation, which he locates at the level of individual character and style of praxis, judged in the light of convention; and on the other hand the gods. That raises the question of what Pausanias' defence would be to the charge of instrumentalizing Eros. Pausanias could be seen as praising erotic praxis as a way to get what one wants: wisdom and a reputation for virtue, if one is take his proposal seriously, or for the older man to get the pleasure which comes from sexual favors, if one views it cynically.

\subsection{Ethical Critique}

Both speakers must face the criticism that they fail to create space for a critique of prevailing ethical norms which is sufficiently radical. Socrates will, after all, praise in the end multiple forms of erotic praxis, both heterosexual and homosexual. Pausanias, by seeming to adopt a focus on polis-specific convention, could appear to limit his possibilities to critique the prevailing ethical norms in a given society. 
Yet in neither case is this criticism fair. Socrates' answer to it is that his account re-grounds the ethics of Eros, dethroning Eros from the divine status suggested by the previous speakers' extensions of contemporary discourses. Diotima's account depends on an elusive, all-filling good, which, against contemporary views, is graspable neither by convention, nor by the physical nature of things, nor in direct relation to polytheistic religion. He later extends the realms of Eros still more explicitly from those which were conventionally recognized-physical procreation and ethical fruitfulness in virtue transmission - to the realm of spiritual and philosophical enlightenment in the revelation of absolute beauty.

Pausanias' answer to the criticism is that he has not accepted prevailing social conventions in every case. Rather, some conventions were said to be inadequate or need revising, either by individuals or societies. The next question is whether Pausanias leaves himself any adequate basis for evaluation of conventions. He cannot say that the ethical account of the praiseworthiness of the good Eros lies in the goodness of the gods, for the other Eros is unpraiseworthy. To say, one will pursue virtue, if one is the right kind of person, and so inspired by the relevant divinities to seek it, is to take the notion of virtue for granted, while marginalizing the role of the gods. At the level of convention, Pausanias seems to focus on systematized rules with negative prohibitions (Pickstock 1998, p. 39), a focus which seems inconsistent with a virtue ethic and with the implied degree of radical revisability. Pausanias' refusal to accept an ethical evaluation of a praxis seems in the end to individualize ethical judgements: he will judge what conventions are right. 'The act is absolute. But that is only a step away from permitting all acts, or the post hoc definition of man by his acts' (Rosen 1987, p. 82). It is as if the sophistic rhetor can set himself up as judge over Eros, to judge the goodness of the god. The claim that older lovers were motivated by the virtuous desire to educate the next generation would have been viewed cynically by contemporary readers, and Pausanias' proposed ethical framework, unmoored from religious sensibility and the stable use of language, will not have decreased that cynicism.

The sophists put their emphasis on language. That is consistent with the idea that Eros, in its better form, encouraging great thoughts, does not sit happily alongside tyranny. For Pausanias, Eros in Athens is inherently linked to discursiveness and the making of speeches; and to philosophy and the freedom to think (Ludwig 2002). Pausanias promised subtlety (poikilon), and indeed this is a view far more complex than that outlined by Phaedrus at 178c3-179b2 of the needs of the democratic city and how it can flourish. It is notable that, unlike Phaedrus, he replaces talk of love of honor, and the martial virtues, with wisdom (sophia, 184d2) (Grube 1958, p. 98; Taylor 1960, pp. 214-16). This could seem enlightened; or be judged more harshly, by Polyneices or a traditionalist, as a commitment to mere 'cleverness.' The speech could then seem 'an exceedingly smart piece of special pleading' (Bury [1932] 1973, p. xxvi). Such harsher judgements have a political dimension. For all Pausanias says about the democratic value of discourse, it is against him that his account provides no means to resist the sophistical manipulation of ethical evaluation by the powerful (Pickstock 1998, p. 42); if it does not in fact constitute an example of it (Bury [1932] 1973, p. xxvii). To a traditionalist, if the emphasis is on terminology, then it is the more concerning that terminology has become isolated and unreliable. This could suggest that, after the breakdown of the heroic ethos, the life of the polis is fracturing in alarming ways, with even the terms in which ethical reflection must occur now in question (Gadamer 1986; Pickstock 1998, p. 38; Hunter 2004, p. 52). This is a problem for Pausanias himself, since his own objectives are 'dependent on the polis' (Rosen 1987, p. 64).

\subsection{Doxology as Mediation}

Both speakers take doxology itself as something which mediates, but in different relationships. Pausanias' account is to be taken as a serious doxology, not as facile sophistry, nor a political manifesto to which the theology is wholly irrelevant. Pausanias offers a coherent account of the plurality of Eros, which engages contemporary religious ideas and combines them with an understanding of ethics as convention, applying a sophistical understanding of language. The classificatory scheme he develops represents a triumph of sorts, balancing and synthesizing a series of hard-to-reconcile elements: some 
Eros appears by convention unpraiseworthy, yet evaluation is to be based on convention, yet such Eros is still Eros since terminology is terminology, yet Eros is divine. In such a doxology, the sophist by his skill mediates between anarchic incoherence and confusion on the one hand, and showing that what is praised has a place within the clarity of a classified system on the other. It is only when one has heard the sophist that one has the necessary clear, coherent, nuanced understanding of the matter. Sophistic discourse thus mediates, without participation. The teaching which the sophist can offer is an apprenticeship in this skill. Thus, while it may be true that some of the older lovers defended by Pausanias 'will have nothing to teach but the conventions' (Anderson 1993, p. 28), Pausanias himself can teach not only the conventions but a skill in persuading others what conventions do, or should, prevail. Yet as a result Pausanias' doxology may seem to praise not so much its object, but itself. Relatedly, as doxology, it praises a 'good' Eros which seems 'much rarer than its opposite' (Hunter 2004, p. 48).

Socrates' discourse mediates in a different way. Such theological and philosophical writing reveals not only Eros as mediate, but also itself (Scott and Welton 2009, p. 207). It thereby sheds light on the analogy expressed earlier: that 'Eros is a necessarily a philosopher' (204b5), since philosophy is revealed as no less mediate than Eros. Pausanias' account points to itself, to the classificatory system it explicitly presents. Socrates' doxology positions itself, and indeed Platonic philosophy as a whole, as pointing beyond itself. This philosophy can act as midwife to pregnant souls (Burnyeat 1977; Sheffield 2006a, pp. 89, 211 with n.1). As discourse it can mediate between the person who takes part in it, and a goodness and beauty which to an extent transcend both participant and discourse. This possibility for philosophy to reveal something transcendent is evident from the outset in the introduction by Socrates of Diotima as a priestess, and from Socrates' comment at 206b9 that 'one would need to be a prophet to understand this.'

As Plochmann saw (Plochmann 1971, p. 332), one cannot read the Symposium either as 'a "drama of ideas" pure and simple, nor ... a drama of persons who happen to be talking theory.' Rather both are integrated in a mediation for which the dialogue form itself is entirely appropriate (Gill and McCabe 1996). The richness of apparently ephemeral contextual and relational color in Plato's dialogues enables us to see such sensible and even ephemeral things, and the friendships among us, as revelations of the goodness of the world (Pickstock 2001a, pp. 537, 539). These are Simone Weil's mediate things or metaxu, of which 'no human being should be deprived'; our 'home, country, traditions, culture, and so forth ... which warm and nourish the soul and without which, short of sainthood, a human life is not possible' (Weil 2002, p. 147; Lamascus 2016, p. 98).

All such mediating theological discourse of participation has the potential to take liturgical form. Liturgy is likewise a discourse which mediates, connecting humans to the divine. Relatedly, it has been said that theology is best begun by reflecting on liturgical practice (Milbank 2009, p. 339). The beginning of the Symposium calls for a liturgy, and specifically a doxology, of Eros. Only Socrates' discourse satisfies the request, paradoxically by placing Eros in its proper mediating relation to the divine. This paradox can be generalized. The more whole-hearted the commitment to a transcendent good, the more modestly are Eros, philosophical theology, liturgy and language itself revealed as (mere) mediators.

\section{Conclusions}

This paper has argued that the engagement between the positions of Pausanias and Socrates is more important than has previously been seen. Most critics have seen Pausanias and Socrates as focused on separate types of plurality, while their shared focus on praxis has been largely disregarded. Against such approaches, the reading presented here has applied the frame of doxology, which the dialogue itself proposes, to bring the semantic, ethical, political and theological issues raised in each of these passages into focus together. The comparison between Pausanias' speech and this section of Socrates' speech has shown how related these issues are to each other, and how much light they shed on each other. 
Both speakers doxologize, theologizing the plurality of erotic praxis, and opposing a unitary account. Yet Pausanian classification turns out to provide a fragile basis for doxology. It is the mediating theological discourse of participation put forward in Socrates' speech, which proves adequate to be, in Pickstock's phrase, consummated as liturgy.

Funding: This research was partly funded by a PhD grant from the UK's Arts and Humanities Research Council.

Conflicts of Interest: The author declares no conflict of interest.

\section{References}

Allen, Reginald. 1993. The Dialogues of Plato, Volume 2: The Symposium. London: Yale University Press.

Anderson, Daniel. 1993. The Masks of Dionysus: A Commentary on Plato's Symposium. Albany: State University of New York Press.

Baur, Paul. 1902. Eileithyia. University of Missouri Studies I: 208-97.

Breitenberger, Barbara. 2007. Aphrodite and Eros: The Development of Erotic Mythology in Early Greek Poetry and Cult. New York: Routledge.

Brisson, Luc. 2006. Agathon, Pausanias, and Diotima in Plato's Symposium: Paiderastia and Philosophia. In Plato's Symposium: Issues in Interpretation and Reception. Edited by James Lesher, Debra Nails and Frisbee Sheffield. Cambridge: Harvard UP, pp. 229-51.

Burnyeat, Myles. 1977. Socratic Midwifery, Platonic Inspiration. Bulletin of the Institute of Classical Studies 24: 7-16. [CrossRef]

Bury, Robert. 1973. The Symposium of Plato. Cambridge: Heffer. First published 1932.

Cleary, J. John. 2007. Erotic Paideia in Plato's Symposium. In Plato's Symposium: Proceedings of the Fifth Symposium Platonicum Pragense. Edited by Aleš Havlíček and Martin Cajthaml. Prague: OIKOYMENH, pp. 53-72. Reprinted in Studies on Plato, Aristotle and Proclus: The Collected Essays on Ancient Philosophy of John Cleary. Edited by John M. Dillon. Leiden: Brill.

Corrigan, Kevin, and Elena Glazov-Corrigan. 2004. Plato's Dialectic at Play: Argument, Structure, and Myth in Plato's Symposium. Pennsylvania: Pennsylvania State University Press.

Costa, Mario. 2006. For the Love of God: The Death of Desire and the Gift of Life. In Toward a Theology of Eros: Transfiguring Passion at the Limits of Discipline. Edited by Virginia Burrus and Catherine Keller. New York: Fordham UP.

de Romilly, Jacqueline. 1984. D’Euripide a Platon: L'exemple des Pheniciennes. Estudios Clasicos XXVI: 259-65.

Dorter, Kenneth. 1969. The Significance of the Speeches in Plato's Symposium. Philosophy \& Rhetoric 2: 215-34.

Dover, Kenneth. 1978. Greek Homosexuality. Cambridge: Harvard University Press.

Eidinow, Esther, Julia Kindt, and Robin Osborne, eds. 2016. Theologies of Ancient Greek Religion. Cambridge: CUP. Gadamer, Hans-Georg. 1986. The Idea of the Good in Platonic-Aristotelian Philosophy. New Haven and London: Yale University Press.

Gaita, Raimond. 1999. A Common Humanity: Thinking about Love \& Truth \& Justice. London and New York: Routledge. Gaita, Raimond. 2004. Good and Evil: An Absolute Conception, rev. ed. London and New York: Routledge.

Gill, Christopher, and Mary Margaret McCabe. 1996. Form and Argument in Late Plato. Oxford: Clarendon.

Grube, George M. A. 1958. Plato's Thought. Boston: Beacon Press.

Halperin, David. 1986. Plato And Erotic Reciprocity. Classical Antiquity 5: 60-80. [CrossRef]

Hunter, Richard. 2004. Plato's Symposium. Oxford: Oxford University Press.

Jowett, Benjamin. 1871. The Dialogues of Plato. Oxford: Clarendon Press.

Kerr, Fergus. 1987. Charity as Friendship. In Language, Meaning and God: Essays in Honour of Herbert McCabe OP. Edited by Brian Davies. London: Geoffrey Chapman, pp. 1-23.

Lamascus, Lorelle. 2016. The Poverty of Eros in Plato's Symposium. New York: Bloomsbury.

Ludwig, Paul Walter. 2002. Eros and Polis. Cambridge: CUP.

McCabe, Mary Margaret. 1994. Plato's Individuals. Princeton: Princeton UP.

Meltzer, Gary S. 2006. Euripides and the Poetics of Nostalgia. Cambridge: CUP.

Milbank, John. 2009. Postmodern Critical Augustinianism. In The Future of Love. London: SCM Press.

Milbank, John, and Catherine Pickstock. 2002. Truth in Aquinas. New York: Routledge. 
Most, Glenn W. 2005. Six Remarks on Platonic Eros. In Erotikon: Essays on Eros, Ancient and Modern. Edited by Shadi Bartsch and Thomas Bartscherer. Chicago: UCP.

Murdoch, Iris. 1998. The Fire and the Sun: Why Plato Banished the Artists. In Existentialists and Mystics: Writings on Philosophy and Literature. Edited by Peter Conradi. New York: Penguin. First published 1977.

Murdoch, Iris. 1993. Metaphysics as a Guide to Morals. New York: Penguin.

Nightingale, Andrea. 1993. The Folly of Praise: Plato's Critique of Encomiastic Discourse in the Lysis and Symposium. Classical Quarterly 43: 112-30. [CrossRef]

Nightingale, Andrea. 1995. Genres in Dialogue: Plato and the Construct of Philosophy. Cambridge: CUP.

Nola, Robert. 1990. On Some Neglected Minor Speakers in Plato's Symposium: Phaedrus and Pausanias. Prudentia 22: 54-73.

Nygren, Anders. 1953. Agape and Eros. Translated by Philip Watson. Philadelphia: Westminster Press.

Osborne, Catherine. 1994. Eros Unveiled: Plato and the God of Love. Oxford: Clarendon.

Page, Denys Lionel. 1962. Poetae Melici Graeci. Oxford: Clarendon.

Pender, Elizabeth. 1992. Spiritual Pregnancy in Plato's Symposium. The Classical Quarterly 42: 72-86. [CrossRef] [PubMed]

Pickstock, Catherine. 1998. After Writing: On the Liturgical Consummation of Philosophy. Oxford: Blackwell.

Pickstock, Catherine. 2001a. The Problem of Reported Speech: Friendship and Philosophy in Plato's "Lysis" and "Symposium". New Blackfriars 82: 525-40. [CrossRef]

Pickstock, Catherine. 2001b. Justice and Prudence: Principles of Order in the Platonic City. Heythrop Journal 42: 269-82. [CrossRef]

Plochmann, George. 1971. Supporting Themes in the Symposium. In Essays in Ancient Greek Philosophy. Edited by John Peter Anton and Anthony Preus. Albany: State University of New York Press, vol. 1, pp. 328-44.

Price, Anthony. 1997. Love and Friendship in Plato and Aristotle. Oxford: Clarendon. First published 1989.

Ritchie, Angus. 2012. From Morality to Metaphysics: The Theistic Implications of Our Ethical Commitments. Oxford: OUP.

Rosen, Stanley. 1987. Plato's Symposium, 2nd ed. New Haven: Yale University Press.

Rowe, Christopher. 1998. Plato's Symposium. Warminster: Aris and Phillips.

Sansone, David. 1996. Plato and Euripides. Illinois Classical Studies 21: 35-67.

Scott, Gary, and William Welton. 2009. Erotic Wisdom: Philosophy and Intermediacy in Plato's Symposium. Albany: State University of New York Press.

Sedley, David. 2006. The speech of Agathon in Plato's Symposium. In The Virtuous Life in Greek Ethics. Edited by Burkhard Reis. Cambridge: CUP, pp. 49-67.

Sheffield, Frisbee. 2006a. Plato's Symposium: The Ethics of Desire. Oxford: OUP.

Sheffield, Frisbee. 2006b. The Role of the Earlier Speeches in The Symposium: Plato's Endoxic Method? In Plato's Symposium: Issues in Interpretation and Reception. Edited by James Lesher, Debra Nails and Frisbee Sheffield. Cambridge: Harvard UP.

Smothers, Edgar. 1947. Kalos in Acclamation. Traditio 5: 1-57. [CrossRef]

Strauss, Leo. 2001. On Plato's Symposium. Edited by Seth Benardete. Chicago: University of Chicago Press.

Taylor, Alfred Edward. 1960. Plato: The Man and His Work. London: Methuen.

Usener, Hermann. 1868. Kallone. Rheinisches Museum Für Philologie 23: 316-77.

Vlastos, Gregory. 1973. The Individual as an Object of Love in Plato. In Platonic Studies. Princeton: Princeton UP. Weil, Simone. 1957. Intimations of Christianity among the Ancient Greeks. New York: Routledge.

Weil, Simone. 2002. Gravity and Grace. Translated by Emma Crawford, and Mario von der Ruhr. London: Routledge. Willetts, Ronald. 1958. Cretan Eileithyia. The Classical Quarterly 8: 221-23. [CrossRef]

(C) 2018 by the author. Licensee MDPI, Basel, Switzerland. This article is an open access article distributed under the terms and conditions of the Creative Commons Attribution (CC BY) license (http:/ / creativecommons.org/licenses/by/4.0/). 